\title{
LAICIDADE E CRÍTICA DA ASSIMILAÇÃO CULTURAL E RELIGIOSA: NOTAS SOBRE UM PLURALISMO HERÉTICO ${ }^{1}$
}

\section{SECULARISM AND THE CRITIQUE OF CULTURAL AND RELIGIOUS ASSIMILATION: NOTES ON HERETICAL PLURALISM}

\section{Douglas Ferreira Barros ${ }^{1}$}

\section{RESUMO}

$\mathrm{O}$ artigo tem por objetivo debater aspectos da laicidade e da política secular à luz do pluralismo herético inclusivo. Habermas defende que a experiência da laicidade em sociedades democráticas se efetiva quando estabelecida em acordo com critérios como: submissão dos dogmas religiosos ao princípio da pluralidade; aceitação dos pressupostos laicos para as instituições públicas: escolas, instituições governamentais; submissão das visões de mundo aos princípios laicos das democracias liberais. Alguns críticos vêem que alguns desses princípios podem ser tomados como plataformas de assimilação cultural e religiosa. Pensado de um ponto de vista da laicidade, esse conjunto de princípios se justificaria como barreira de contenção aos valores e visões de mundo que não se enquadram na normalidade institucional e de valores democráticos. A defesa da laicidade em sentido não assimilacionista comporta a defesa de um pluralismo herético. O método de trabalho adotado é o da análise de obras filosóficas e textos relacionados às mesmas que debatem o tema da laicidade, da assimilação cultural e do pluralismo. Ao final, pretendemos delinear o escopo desse pluralismo, que não antecipa a assimilação em nome da democracia ou do uso da razão cosmopolita.

Palavras-chave: laicidade, religião, modernidade, pluralismo herético .

\footnotetext{
${ }^{1}$ Doutor em Filosofia pela USP (2004). Professor da Faculdade de Filosofia e docente do quadro permanente de professores do PPG em Ciências da Religião da PUC-Campinas - Campinas - Brasil. Graduação em Filosofia pela UFGo (1992), mestre em Filosofia - USP (1998) (Bolsa - CNPQ), Stage de doctorat-sanduíche - École des Hautes Études en Sciences Sociales - Paris (2001-2003) (bolsa CAPES) e doutorado em Filosofia - USP (2004) (bolsa CNPQ). Pós-doutorado (03/2006-03/2007) USP (bolsa FAPESP). Participações do Conselho da Pró-Reitoria de Pós-Graduação e Pesquisa da PUC-Campinas (08/2009-08/2011; 01/2020-atual); Comitê de Ética em Pesquisa (PUC-Campinas): 2016-atual. Coordrenador do Departamento de Relações Externas, para acordos com IES estrangeiras (08/2011- 01/2018). Líder do Grupo de Pesquisa: Ética, Política e Religião: questões de fundamentação (02/2015-atual). Residente em São Paulo, capital. Afiliação: Pontifícia Universidade Católica de Campinas - PUC-Campinas. Lattes: http://lattes.cnpq.br/4396269727605413. ORCiD: https://orcid.org/00000002-7030-1031. E-mail:douglasfbarros@gmail.com
} 


\begin{abstract}
The article aims to discuss aspects of secularism and secular politics based on the notion that inclusive pluralism has an heretic dimension. Habermas argues that the experience of secularism in democratic societies is effective when established according to criteria such as: submission of religious dogmas to the principle of plurality; acceptance of secular assumptions for public institutions: schools, government institutions and submission of worldviews to the secular principles of liberal democracies. Thought from a point of view of secularism, this set of principles is justified as a barrier of containment to values and worldviews that do not fit into the institutional normality and democratic values. But, the philosopher recognises that some aspects of this model of secularism have failed. The perspective of an heretical pluralism intends to include many different world views in the public space context. The defense of secularism in a non-assimilationist sense entails the defense of an heretical pluralism. The method used is the analysis of the philosophical works and texts related to this subject. As final results we want to delineate the scope of this pluralism, which does not preempt assimilation in the name of democracy or the use of a cosmopolitan reason.
\end{abstract}

Keywords: secularism, religion, modernity, heretical pluralism.

\title{
1. SECULARIZAÇÃO E LAICIDADE EM UMA SOCIEDADE PÓS-METAFÍSICA
}

Entre as teses sobre a secularização na contemporaneidade, uma das que maior repercussão produziu foi a que permeou a discussão entre Habermas e Ratzinger (2005). Nesse texto, Habermas faz a defesa de uma secularização nos marcos de um liberalismo político de matriz republicanokantiana. Isto é, defende uma posição que dispensa as "presunções de ordem cosmológica ou de história da salvação em que se baseiam as doutrinas clássicas e religiosas do direito natural" (2005, p.27).

Nesse texto, defende-se que os ordenamentos legal e político não mantêm qualquer relação com cosmologias abrangentes ou com as formulações religiosas do direito natural. Evita-se encontrar as raízes e as bases que sustentam os ordenamentos políticos em princípios religiosos; projetar as instituições como locus de acolhida exclusivo das posições e visões de mundo inspiradas e/ou fundadas em tradições religiosas. O filósofo defende um procedimentalismo democrático, a saber, o ordenamento político e institucional regulado por princípios racionais, o qual: “....se baseia na fundamentação autônoma dos princípios racionais que pode ser aceita racionalmente por todos os cidadãos" (2005, p.32).

Assim, considerando-se que sejam racionais todos os cidadãos que fazem, ou pelo menos desejam fazer, parte da democracia em sentido kantiano na interpretação de Habermas, ou de um Estado secular cuja constituição seja inspirada no liberalismo, nela, os cidadãos devem estar integrados politicamente. Essa integração não pode estar restrita a um modus vivendi: “...essa 
diferenciação das condições de membro não pode esgotar-se numa simples adaptação cognitiva do ethos religioso às leis impostas pela sociedade secular” (2005, p.54). A adaptação não se restringe a um tipo de enquadramento no ethos comunitário, de uma sociedade. Em sentido da base para o alto, a adaptação de que nos fala Habermas diz respeito à aceitação da regulação das ações por princípios entendidos como racionais partilhados necessariamente pelos cidadãos, assim como dos princípios ordenadores das estruturas jurídico-políticas democráticas. Há portanto uma condição prévia a ser estabelecida no ordenamento social para que as religiões estejam integradas à esfera pública: “Antes é necessário que a ordem jurídica universalista e a moral igualitária da sociedade sejam de tal maneira conectadas internamente ao ethos da comunidade e que um elemento decorra consistentemente do outro" (2005, p.54).

A comunidade religiosa, qualquer que seja ela localizada em sociedades democráticas ordenadas segundo princípios normativos racionais, se vê impelida a se integrar desde que esteja disposta a se confrontar, ou estabelecer um relacionamento "autorreflexivo com os limites do iluminismo" (2005, p.55). A esfera pública conserva os direitos racionais e universais que asseguram tanto a liberdade de credo, nos limites da liberdade política, quanto aquela das decisões de cada indivíduo não crente acerca de suas identificações pessoais: gênero, engajamentos políticos etc., nos limites das suas liberdades individuais e políticas.

Habermas afirma que a consciência secular tem que pagar seu tributo "para entrar no gozo da liberdade religiosa negativa" (2002, p.55). A liberdade religiosa negativa, na analogia ao termo presente na filosofia política de Berlin (1969), seria aquela experimentada no plano privado, sem qualquer intenção ou ato de interferência na estrtutura jurídico política que abriga os cidadãos. Essa liberdade se efetivaria dentro de limites onde os fundamentos religiosos e os princípios do iluminismo não colidem entre si. Diz o filósofo:

A concepção de tolerância de sociedades pluralistas de constituição liberal não exige apenas dos crentes que entendam, em suas relações com os descrentes e os crentes de outras religiões, que precisam contar sensatamente com a continuidade de um dissenso, pois numa cultura política liberal exige-se a mesma compreensão também dos descrentes no relacionamento com os religiosos (2005, p.55).

Desse modo, o aspecto que nos parece coerente em relação à ideia mesma de democracia é que a tese da laicidade habermasiana não defende a supremacia de qualquer posição entre os ocupantes do espaço público. A herança iluminista faz com que esse filósofo suponha e defenda a neutralidade do poder de Estado. Os agentes políticos, religiosos ou não, encontram-se em posição simétrica no espaço público e em face das instituições estatais: tanto tomam como legítima a participação de religiosos em contexto público, a defesa de visões de mundo abrangentes e posicionamentos amparados em certezas da fé, quanto têm garantido o direito de se mafestarem em oposição a taios certezas e apresentarem visões de mundo distintas. 
a neutralidade ideológica do poder do Estado que garante as mesmas liberdades éticas a todos os cidadãos é incompatível com a generalização política de uma visão do mundo secularizada. Em seu papel de cidadãos do Estado, os cidadãos secularizados não podem nem contestar em princípio o potencial de verdade das visões religiosas do mundo, nem negar aos concidadãos religiosos o direito de contribuir para os debates públicos servindo-se de uma linguagem religiosa. Uma cultura política liberal pode até esperar dos cidadãos secularizados que participem de esforços de traduzir as contribuições relevantes em linguagem religiosa para uma linguagem que seja acessível publicamente (2005, p.57).

\section{LAICIDADE, IMIGRAÇÃO E ASSIMILAÇÃO INTENCIONAL}

Ainda que a formulação de Habermas defenda, por um lado, que as religiões estejam obrigadas a se defrontarem com os princípios do iluminismo, por outro, ela sustenta a não uniformidade ou a não generalização política de um princípio de secularização estrito. Os cidadãos não religiosos estão submetidos às mesmas obrigações dos religiosos quanto à aceitação de posições políticas públicas. O princípio regulador do ordenamento político permanece para o conjunto dos cidadãos aquela regra geral, segundo a qual a liberdade pressupõe a conformação das escolhas da ação à norma imperativa aceita por todo e qualquer ser racional. A moldura habermasiana parece nesse texto respeitar com perfeição os limites estabelecidos pela cartilha kantiana acerca da liberdade e do princípio racional regulador das ações humanas livres. Não é absurdo dizer que estamos diante dos fundamentos de sociedades pacificadas e democracias bem estabelecidas e muito bem apresentadas. É o que se poderia concluir até que os limites dessa moldura ético-política tivessem sido confrontados por fatos contemporâneos desafiadores não apenas dos princípios da laicidade, como tambném dos da democracia e da estrutura jurídico-política.

Como é bem sabido pelos mais importantes filósofos, a história é mestra em denunciar as falhas e limites em seus sistemas de pensamento. Perguntado sobre os posicionamentos de alemães e europeus em relação aos imigrates que chegavam à Europa pelo Mediterrâneo, em fuga de catástrofes naturais, guerras e perseguições, entre outros infortúnios, Habermas respondeu:

acho vergonhoso o caráter glacial das recentes decisões em matéria de política do direito de asilo, considerando-se o fato histórico de que os fluxos migratórios provenientes do Sul e do Oriente Próximo também são consequência das nossas próprias culpas, as de uma descolonização fracassada. Podemos ainda nos olhar no espelho sem nos envergonharmos pelas tragédias que ocorrem no Mediterrâneo e que nós deixamos mais ou menos acontecer na ausência da vontade de criar uma cooperação? É claro que simplesmente abrir as portas para todos os refugiados não é possível para nós, mas, na falta de uma política de asilo comum a todos os Estados europeus, que até agora fracassou por causa da falta de vontade dos Estados de entrarem em acordo sobre um critério de repartição, seria necessário que nós modificássemos radicalmente e ao mesmo tempo a nossa 
política em relação aos países de onde os refugiados provêm, em primeiro lugar no que diz respeito à nossa política econômica (2019).

O filósofo constata o fracasso da política de asilo e atribui o cenário à ausência de uma política comum a todos os Estados europeus. Estamos diante da confirmação de que o descompasso entre o direito e as demandas por direitos está nas raízes profundas do absenteísmo europeu em relação aos povos, regiões e países que outrora foram a fonte segura das riquezas e da prosperidade europeias, desde o século XIX. Em outras palavras, poderíamos dizer que a moldura jurídicopolítica vigente na Europa do presente não conseguiu incorporar os princípios do iluminismo em relação aos estrangeiros, muito distante ainda da ideia de um cidadão universal ou do homem como portador de direitos universais. Vale ainda destacar a menção de Habermas ao fato da descolonização fracassada. Afirmação dirigida ao mundo político e à cidadania mesma, tão alheias à ideia da liberdade como princípio regulador das instituições e decisões governamentais.

O mais surpreendente, contudo, é a avaliação acerca do descompasso entre a teoria crítica e o etnocentrismo ocidental. Ao reconhecer a cegueira em relação aos problemas descoloniais marxismo ocidental incluído- Habermas concorda acerca da necessidade da legitimidade da discussão posta em pauta pelo desconstrutivismo, a saber, "a crítica legítima do colonialismo bárbaro e da sua grosseira visão eurocêntrica do mundo" (2019). Habermas insiste na necessidade de revisão de pressupostos que ampararam e fundamentam a moldura jurídico-política europeia. Ele se pergunta: "O que é necessário rever?"; emenda na sequência: "Sem sombra de dúvida, a aplicação incrivelmente seletiva dos supostos critérios universais do Ocidente. Mas também é preciso rever os critérios do universalismo ocidental próprios da razão? Por exemplo, conceitos como os de direitos humanos e de evolução social? Não são perguntas simples de responder". ${ }^{2}$

O que seria essa "aplicação seletiva dos critérios universais do Ocidente" senão uma negação da ideia de um arranjo regulador ao qual cidadãos e comunidades, quaisquer que sejam eles, são portadores dos mesmos direitos. Europeus e países que abrigam povos distintos deveriam se submeter com a condição de ver seus cidadãos portadores dos mesmos direitos. A desconfiança -quase admitindo que algo em seu próprio projeto teria falhado- está claramente expressa na referência aos princípios como "supostos critérios universais". Parece claro que a desconfiança que o aplaca atinge até um dos fundamentos de seu trabalho em sequência ao projeto iluminista moderno: "os critérios do universalismo ocidental próprios da razão". Veja-se que a necessidade de revisão dos mesmos é-nos apresentada como questão, assim como a validade de conceitos como direitos humanos e evolução social. Parece claro que o problema da imigração e a dificuldade de acolhida dos estrangeiros e dos diferentes impõe uma suspeita de tal modo contundente que confirma os limites de teorias que advogam em favor de princípios e conceitos universais. 
O que o caso da imigração tem a ver com a laicidade? Ora, as suspeitas sobre os estrangeiros se vinculam não apenas a sua condição desterrada, como também aos costumes e às religiões de origem, geralmente não cristãs. A não aplicação seletiva dos supostos critérios universais, se pudermos emprestar os termos de Habermas, talvez mostre que os mesmos se prestam mais como instrumento orientado para a assimilação cultural e religiosa do que aos fins do projeto iluminista. É um avanço que o filósofo herdeiro do ideal de emancipação pela razão universal e da democracia procedimental reconheça que haja aspectos do projeto a ser revistos. Cabe perguntar: a assimilação intencional não seria a demonstração clara de que, desde o início, o iluminismo não desejou a formação de uma sociedade de cidadãos iguais em direitos a partir dos homens diferentes quanto a suas visões de mundo? Que aspecto de tal revisão poderia ser posto à prova?

\section{ESTADO, LAICIDADE E PLURALISMO}

A heresia não existe mais na religião: ela existe no Estado. Koselleck destacou a frase para atestar a radicalidade da transição, em 1590, do direito de crença para o Estado. O dito Cuius régio, eius religio [de quem o território, dele a religião] expressaria "o fato de que os príncipes, qualquer que fosse a confissão que professassem, erguiam-se, em sua qualidade de príncipes, sobre os partidos religiosos" (2006, p.27). Depois que as guerras de religião devastaram inúmeras cidades, regiões da França tivessem tensionado a sociabilidade entre os religiosos alemães protestantes e católicos, tais povos "foram capazes de perceber que poderiam fazer do princípio da igualdade religiosa a base para a paz" (p.27). A garantia desse princípio de paz repousava no Estado. Cada príncipe assegurava integridade religiosa aos fiéis: a autoridade política e a estrutura do Estado assumiram a condição de fiadores da convivência pacífica entre súditos alinhados a diferentes credos. Entre os benefícios gerados pelo Estado concentrador da autoridade política, agora com relativa ascendência sobre as autoridades religiosas, está a garantia da pacificação entre os crentes, a possibilidade de convivência plural.

A mudança destacada por Koselleck coloca em primeiro plano a tese de que na política moderna o prognóstico, a previsão racional, substitui as antigas profecias religiosas (2006, p.27). O cálculo político é tomado como sinal de maestria nas artes de governar, tanto na Itália dos séculos XV e XVI -a terra natal da política moderna-, quanto nas cortes europeias dos séculos XVII e XVIII. Os escritos de Bodin sobre a história humana, a separação entre história natural e humana, afastam o peso das sentenças terminativas que apontavam o encontro marcado da humanidade com o juízo final. Abrem-se novas possibilidades de ação aos homens, na mesma medida em que a história humana não se desenrola conforme roteiros descritos pelas visões proféticas. Os políticos, não mais reféns dos partidos religiosos e suas sentenças acerca da chegada do juízo final, valorizam 
os problemas temporais e deixam de orientar suas ações com vistas à eternidade. Aí tem lugar a conclusão segundo a qual: "L'heresie n'est plus auiourd'huy en la Religion; elle est en I'Estat" (2006, p.27).

A heresia abrigada no Estado tornava mais livres os homens para professar diferentes doutrinas, participar de cultos e se orientar por líderes cristãos que não os do catolicismo, as inclinações e preferências religiosas dos súditos poderiam não espelhar aquelas do rei: os partidos religiosos não detinham mais o controle do poder político. Koselleck destaca que a paz entre os religiosos da Europa resultou do esgotamento dos povos e não de uma deliberação pessoal em acordo com qualquer princípio elevado da moralidade. O esgotamento das guerras foi, assim, ordenado pelos estados. "Assegurar a paz é tarefa do Estado" (2006, p.29). Está aí, portanto, um dos elementos estruturantes da legitimidade do estado moderno: a capacidade do poder político de submeter a uma regra comum os partidos religiosos.

Jean Bodin foi o filósofo que se envolveu com o grave imblóglio das guerras de religião na França e se ocupou de pensar um poder político que não fosse refém das particularidades religiosas (doutrinas, ritos, interpretações, interesses). Está aí, diz Koselleck, a gênese do Estado autônomo (2006, p.29). Entenda-se essa autonomia como uma disposição para reprimir as previsões apocalípticas, que reduziam as expectativas gerais quanto ao futuro dos povos e estados e abreviavam a necessidade de imposição de defesas àqueles grupos e pessoas identificados às ameaças detonadoras da ira divina. Entre outros monopólios, o Estado se apropriou do poder de prisão e antecipação do futuro. O objetivo desse controle era o de alargar as expectativas e ampliar os horizontes humanos quanto a novas possibilidades de ação e de escolhas. O mundo cujo futuro estava previsto nas escrituras ou nas visões proféticas deu lugar ao horizonte das imprevisibilidades. As antecipações proféticas dão lugar ao cálculo político, às estratégias de antecipação em relação aos adversários, aos estratagemas para a conquista das instituições políticas e do próprio estado. Inaugura-se uma nova concepção de liberdade de ação, a qual está na base dos movimentos que engendrarão a Revolução Francesa (KOSELLECK, 1999). A modernidade inaugura outra relação entre Estado, poder político e interesses religiosos. Prevalecem os primeiros sobre os segundos. O Estado defende sua autonomia com a laicidade - a separação entre as esferas do exercício do poder sobre o público e do governo sobre a sociedade dos interesses específicos da gestão e do poder religiosos; não mais se abala com o fato de abrigar em si grupos religiosos distintos, ordens crentes que concorrem em suas doutrinas.

Duas questões se impõem aos estados contemporâneos, decorrentes dessa suposta condição de autonomia do Estado em relação à religião. A laicidade e a defesa da separação das ordens e interesses políticos e religiosos tem sido instrumentalizada em favor da assimilação cultural e política em acordo de supostas noções universais ou em benefício da proteção contra o conflito 
religioso? Como entender a laicidade não como porta de entrada da assimilação das experiências religiosas particularidades identificadas como universais, ou pelos elementos supostamente universais balizadores do Estado moderno?

Balibar (2018) afirma que a complexidade da questão teológico política na contemporaneidade se apresenta em muitas dimensões. As fronteiras nacionais e as soberanias que as sustentam são completamente permeáveis às migrações. Q chegada de populações de outros países desencadeiam alterações importantes quanto ao senso comum sobre visões de mundo, moral e costumes dos povos abrigados nesses países. Como se decretasse a definitiva demolição de uma concepção moderna de laicidade, diz Balibar: "é cada vez mais artificial a atribuição do religioso ao âmbito do particular (ou dos 'particularismos'), enquanto o secular (sob a forma de 'razão pública') vem por definição ocupar o lugar do universal” (2018, p.47).

O contexto não nos autoriza a relativizar completamente a importância dessa distinção, mas é o caso de retomá-la exatamente para entender por que a noção de razão pública não se sustenta como ideia reguladora de um poder secular e não identificado a algum particularismo religioso ou político. Ao menos deve-se considerar no cenário contemporâneo a competição entre universalidades que reivindicam para si a posição de guardiãs, cada uma delas, da isenção do poder político e demais instituições no Estado. O tema é instigante e urgente, mas deixemos o debate sobre a disputa entre visões de mundo abrangentes, universalizantes, para outra ocasião. Estejamos atentos, por enquanto, à laicidade.

A proposição de uma laicidade em outros moldes, segundo a perspectiva de Balibar, prioriza a categoria de "difereça antropológica" em relação à de "diferença ontológica". Essa alteração se mostraria importante ao se tratar das diferenças "intratáveis" uma vez que são cruciais, em uma mesma população diversa, e não podemos evitá-las (ou negar sua existência) "nem especificá-las de forma estável, unívoca e incontestável” (2018, p.71). A intenção ao propor tal estratégia de análise é:

\begin{abstract}
chamar a atenção para a eficácia de sistemas simbólicos que são pensados e institucionalizados, não apenas na organização e sacralização das estruturas culturais de poder e hegemonia, mas também no investimento de diferenças antropológicas (como a diferença entre os sexos), o que acentua e radicaliza a distribuição de papéis e práticas que é função básica da cultura uniformizar e inscrever na obviedade do cotidiano (2018, p.73).
\end{abstract}

Opta-se nesse caso por ultrapassar as estruturas de sacralização da hegemonia reforçando as diferenças antropológicas e, por que não acrescentar, históricas. Balibar investe na formulação de um novo tipo de secularismo ou, pensando em termos da laicidade, novos regimes de organização política e jurídica que contemplem a diversidade religiosa, o contexto de novas religiões, algumas delas inclusive lastreadas em antigas tradições e nas referências canônicas monoteístas. A 
radicalidade da posição se pode medir pela seguinte declaração: "isto implica ainda, com toda probabilidade, que o governo e os modos de representação terão que ser reconstruídos em bases diferentes daquelas inventadas pelos Estados-nação industriais no período em que se comprometeram a "dividir o mundo entre si" (2018, p.77).

O que se procura é formular uma "nova articulação cívica" que combina, segundo Balibar, "socialismo, internacionalismo, multiculturalismo e, por assim dizer, um secularismo elevado", promover a própria secularização do secularismo, a saber, "uma forma crítica e autocrítica do que tem sido historicamente pensado e institucionalizado sob essa rubrica" (2018, p.77). Acusam os críticos defensores da armação jurídico-política em vigor, principalmente na Europa, que o autor estaria promovendo uma ingênua revolta de caráter anárquico. Balibar enfatiza não haver cidadania democrática sem instituições, institucionalização e leis (2018, p.77-8), mesmo que não exista forma jurídica invariável. Em benefício da mudança jurídico-política, arremata: “...os Estados e sistemas jurídicos são, precisamente, prisioneiros do particularismo nacional e, portanto, cultural; eles tendem a reproduzir formas de hegemonia comunitária ou, na melhor das hipóteses, a estabelecer seus limites" (2018, p.77-8).

Reafirmar a "profanação" das identidades culturais e suas supostas tradições e as solidariedades sociais decorrente das primeiras é o que nos permitiria reformular a secularização e a laicidade. Balibar aposta em um novo tipo ou algo além do multiculturalismo, que possibilita uma dissociação entre as "figuras tradicionalmente contíguas (embora não idênticas) do estrangeiro (étranger) e do inimigo" (2018, p.70). Ele completa:

A condição para o multiculturalismo é, portanto, também uma política de tradução intercultural que valoriza e fomenta os fenômenos de aliança e hibridização, de múltiplas filiações, que formam a base material para encontros e trocas entre universos culturais distantes, mesmo que tais fenômenos tenham muitos obstáculos a superar e muitas vezes venham ao preço, para o indivíduo, de uma melancolia criada pela experiência do exílio ou, mais simplesmente, dos problemas existenciais inerentes à vida em uma diáspora $(2018$, p.79).

Como se vê, importa sobretudo que as instituições promovam a hibridização e a troca entre universos culturais distantes. A defesa do multiculturalismo é insuficiente para promover esse tipo de rearranjo se as instituições e molduras jurídico-institucionais não acolhem tal intenção conceitual e retórica, no mais das vezes. ${ }^{3}$ Balibar defende que se invista em um novo regime de tradução ou "traduzibilidade" (2018, p.80). E o que vem a ser isso? De fato, a possibilidade de se traduzir um universo cultural e religioso em outro. Nesse caso, as instituições que acolhem e possibilitam essa tradução só poderiam afastar-se dos equívocos da assimilação caso refletissem uma laicidade propositalmente herética. A heresia aqui não se entende como um elemento promotor da iconoclastia, mas como a condição de não aderência da moldura jurídico-política a qualquer 
pressuposto religioso, cultural ou filosófico pretensamente universalista. Balibar reconhece que o "religioso" é intraduzível por si mesmo. Dar voz ao intraduzível dos religiosos, dos diferentes, não como estrangeiros, mas como iguais portadores de mesmos direitos daqueles tidos como os iguais em uma sociedade é o desafio de uma laicidade permeável e não comprometida com a defesa de uma posição hegemônica, unívoca.

\section{LAICIDADE, COSMOPOLITISMO E O PROBLEMA TEOLÓGICO-POLÍTICO}

Destacados escritos sobre o cosmopolitismo na contemporaneidade (Habermas, 2002; Benhabib, 2006) localizam o tema da religião e o das disputas entre religiosos entre os problemas críticos que envolvem a convivência em comum em estados laicos e sociedades secularizadas. Balibar surpreende em sua avaliação pelo fato de entender que o tema da inserção de diferentes grupos religiosos em sociedades laicas possui uma dimensão teológico-política (2018, p.53). A questão que envolve religiosos e suas respectivas visões de mundo abrangentes, verdades e doutrinas é do conflito entre universalidades em competição (2018, p.53).

Sempre que uma diferença religiosa ou teológica se torna uma fonte de conflito (e cabe a nós determinar, caso a caso, as condições que cristalizam o conflito ou o tornam antagônico), esse conflito é potencialmente cosmopolítico. É por isso que as noções intimamente relacionadas de cosmopolitismo (herdadas das antigas e clássicas tradições filosóficas) e cosmopolítica (intensificadas pelos efeitos da globalização) não podem mais ser articuladas de forma linear, como se fosse possível articular uma idéia com sua tradução em realidades e atos $(2018$, p.53).

Balibar se alinha ao diagnóstico acerca das posições defensoras de uma racionalidade e de princípios políticos ocidentais sem dar atenção às críticas pós-coloniais. Os casos mais emblemáticos dessas posições acríticas servem, ao final das contas, para metamorfosear antigas posições políticas colonizadoras em comoventes declarações falsamente humanitárias. A crítica pós-colonial é aquela, segundo Mbembe (2019), que "desnuda a violência indiferente a uma ideia particular de razão quanto o fosso que, nas condições coloniais, separa o pensamento ético europeu de suas decisões práticas, políticas e simbólicas" (p.83). O pensador camaronês parece se referir à contradição a se constatar entre as belíssimas discussões acerca da liberdade e da autonomia dos povos produzidas nos grandes centros difusores do pensamento crítico europeu e as posições políticas e decisões governamentais europeias em face dos imigrantes chegados de inúmeras regiões pobres mundo afora.

Mbembe sublinha a importância de se desconstruir a prosa colonial, "a montagem mental, as representações e formas simbólicas" $(2019$, p.84) pela qual os supostos defensores da liberdade implementam projetos imperiais e ignoram os dramas humanitários de povos explorados por 
décadas ou séculos. Assim, a perspectiva crítica de Mbembe, tal como a de Balibar, busca desmontar a linguagem dupla do humanismo europeu -de emancipação na Europa e identificados aos subversores e intransigentes nas colônias. Intenta-se desconstruir um conjunto de mentiras expressão do camaronês- envelopadas em fabulações supostamente amistosas e tolerantes, que escondem intenções de submissão e as pré[concepções que amparam os juízos de superioridade e em relação aos colonizados.

Assim como Mbembe, Balibar se mostra cético em relação à retórica do universalismo aliada do humanismo. O primeiro afirma que essa junção serviu de fachada para o emprego da força - “uma força que não sabe escutar e que não sabe se transformar" (2019, p.85). O segundo destaca como relevante um multiculturalismo que se consuma num pluralismo constitucional, a fim de que "para cada indivíduo, sua filiação a uma determinada comunidade goze de proteção legal e do mesmo reconhecimento concedido a todos os outros; esta filiação comunitária é, em última instância, o vetor da educação e a condição para a dignidade pessoal" (2018, p.54). O horizonte histórico dessa perspectiva é o do "processo interminável de hibridização e interação entre comunidades" (2018, p.54). Ainda que o discurso dominante nos meios políticos e acadêmicos tenha rejeitado as várias formas de multiculturalismo, diz Balibar, talvez essa ideia seja a que mais poderia de fato mostrar que a Europa possa se engajar em outro processo de aproximação com povos distintos. E conclui: "o que torna os sujeitos capazes de individualização e metamorfose histórica é sua aptidão para a tradução e, portanto, para a desidentificação, que é pelo menos virtual e pode chegar ao ponto de se tornar "dupla consciência"' (2018, p.54). Concretamente, a discussão sobre o "retorno do religioso" ou do "sagrado" mergulha o ideal do cosmopolitismo na crise e na desconfiança.

O tema da tradução, a traduzibilidade de elementos específicos das religiões e a disponibilidade de acolhida dos diferentes, os estranhos, os estrangeiros, é uma porta para a solução do impasse da crise sobre o cosmopolitismo. Vale destacar que o tema está envolto em tanto ceticismo que há os que se referem a essa questão como a do planetarismo (SPIVAK, 2003) e não do cosmopolitismo. Mas, a possibilidade de que religiões e povos se encontrem em posição de manifestar suas posições e possam traduzi-las aos demais - e não se apresentarem simplesmente à assimilação de princípios universalistas- se materializa na abertura de instituições e leis voltadas a esse exercício. O desafio a ser transposto nos países onde os conflitos se apresentam reside em que as legislações e instituições estão presas ãos particularismos (BALIBAR, 2018, p. 77). Acima de tudo, os estados são inseparáveis (por mais alto que proclamem sua devoção à laicidade) das construções teológico-políticas nas quais foram concebidas. Balibar comenta que, não raro, formas de poder que se proclamam assentadas na ideia da laicidade tendem a sacralizar essa posição como se isso fosse suficiente para resolver o problema da imposição de assimilação cultural e religiosa 
sobre os diferentes. Mesmo a França e a sua tão consagrada defesa da laicidade teriam feito brotar um tipo de imunização discursiva, segundo o qual a laicidade é inerente às instituições todas que a compõem: "assim [o Estado francês] é colocado fora do alcance da contestação e do conflito de interpretações" (2018, p.78). Os estados se imunizariam das críticas a suas posições restritivas, exclusivistas e supremacistas, no final das contas, por assumirem posições suavemente laicas e autoelogiosamente democráticas, mesmo que se notem suas instituições impermeáveis às demandas e manifestações de cidadãos cujas religiosidades conflitam e concorrem com aquelas tradicionais nesses mesmos estados laicos.

Que saída se poderia vislumbrar em face das investidas em favor dos assimilacionismos? As soluções não poderiam desprezar, em favor da traduzibilidade, processos e instituições promotoras da comunicação cultural e civilizacional dos antagonismos religiosos e dos seus elementos motivadores. Balibar reconhece que o debate sobre o multiculturalismo está "comprometido em todos os lugares hoje em dia por discussões mortais de racismo pós-colonial, um ressurgimento do nacionalismo e reações defensivas provocadas pela própria globalização, ao ponto de 'profanar' as identidades culturais e desfazer as solidariedades sociais" (2019, p.78). São esses os elementos promotores da classificação dos diferentes como os inimigos, as ameaças -sejam eles cidadãos legalmente reconhecidos como tal ou aqueles sem documentos e mesmo os refugiados, principalmente, os apátridas. A retórica de aproximação e mesmo identificação dos diferentes com essa imagem do estranho ou do inimigo fere de morte a possibilidade de emergência da convivência plural.

Fomentar alianças e hibridização supõe a reformulação completa das noções de identidade que constituem a base da compreensão atual do que seja um povo, uma nação, uma cultura. A pacificação dos conflitos religiosos e culturais, "ou mesmo a sua comversão ou sublimação em ideal, diz Balibar, não se realizam no modo de um multiculturalismo estanque. A tradução a que se refere esse autor se abre aos multifacetamentos e intercâmbios religiosos e culturais. Isso exige uma compreensão e uma aceitação plástica de doutrinas e princípios religiosos, uma compreensão mais difusa de elementos demarcadores da cultura de um povo, dos caracteres constitutivos da nação.

O que reina entre os axiomas religiosos não é necessariamente a guerra (pois, como lembrei anteriormente, as causas das 'guerras de religião' na verdade nunca são simplesmente ideológicas), mas o que eu chamei de conflito de universalidades; graças ao qual a diferença é reduzida a, ou representada de acordo com, um certo código, uma certa lei simbólica. Aqui é o próprio regime de tradução ou 'traduzibilidade' que deve mudar (2018, p.79).

Que novo regime será esse? A mera possibilidade de se traduzir um universo religioso para outro exige considerarmos que os elementos religiosos em tradução se prestam a uma compreensão e a uma aceitação mais flexível, plástica. O desafio reside no fato de que, comumente, o religioso demarca os limites do intraduzível. Cabe, contudo, nos perguntarmos sobre o estatuto desse 
intraduzível. Seria ele impermeável à compreensão alheia por sua própria forma de ser? Seria ele uma estrutura cuja compreensão é inviolável aos que dela não participam? A intraduzibilidade refletiria, na verdade, o fechamento à compreensão alheia?

Os meios estatais e legais, diz Balibar, não são suficientes para propiciar a traduzibilidade religiosa. Eles podem, contudo, tornar viável o encontro entre as religiões. A indiferença estatal e das leis ao esforço pela tradução religiosa termina por favorecer diretamente as tradições estabelecidas. O afastamento do Estado em face dos conflitos religiosos e de visões de mundo estabelecidos externa a redução de um mal-estar entre verdades universais concorrentes a um problema de diferenças culturais. Não é preciso muito esforço para entendermos que o fato da religião e as religiões em conflito no contexto de sociedades seculares e laicizadas acarreta dimensões da experiência humana coletiva que ultrapassam as diferenças culturais.

Como no caso da heresia instalada no Estado moderno, o fato de que o Estado não mais se torna refém de um credo específico, a traduzibilidade requer a instauração de um tipo de relação das religiões entre si e destas com o Estado. Balibar defende que, mais do que isento e secular, esse elemento possibilitador das novas relações, "o encontro entre religiões", é algo que possui caráter a-religioso. Trata-se de um elemento que não se envolve de forma alguma, que não se gera a partir de qualquer das visões de mundo ou verdades universalizantes em jogo. Completa:

o que torna obliquamente possível o encontro de diferentes religiões, ou permite que estas, em conjunto, possam cultivar uma 'conversa livre' no domínio público, é a introdução ou intervenção ali de um elemento suplementar que é, como tal, areligioso (embora não necessariamente anti-religioso) (2018, p.80).

Antes de pensarmos em uma estrutura, programa, um modelo de leis, esse elemento é atópico, algo que se posiciona interna e externamente às religiões em simultâneo. É algo como "um limite no universo ideológico" pelo qual se evitaria medir a distância ou uma suposta hierarquia entre diferentes axiomas, nos impediria "fazer convergir suas intepretações "para certas regras éticas ou sociais". Assim, se evitaria construir discursos nos quais as diferenças são apresentadas por comparação, fazendo com que respeitem uma ordem emoldurada por pressupostos estabelecidos aleatoriamente às próprias religiões envolvidas na tradução. Tal limite atópico, isto é, os marcos para o desencadeamento de um processo, e não a base ou o seu fundamento, introduziria as religiões umas às outras "fora do quadro de uma dominação codificada ou de uma reconciliação imaginária" (2018, p.80). As características desse limite atópico seriam paradoxais por ao mesmo tempo possibilitarem alianças, filiações distintas, trocas de universos também culturais, sem conduzir o processo a finalidades pré-estabelecidas. Tal política de secularização, digamos assim, teria em certo sentido uma característica herética e propiciaria um pluralismo também de algum modo herético, na medida em que, paradoxalmente, possibilitasse essa traduzibilidade entre 
religiões sem satisfazer, se emoldurar ou se alinhar às suas respectivas matrizes doutrinárias, formuladoras e sistematizadoras das verdades universalizantes.

O limite atópico é um mediador das relações. O fato de que as religiões estabeleceram e realizam trocas entre si -porque a guerra não é a sua razão de existir- nos autoriza a afirmar que ele já existe. Balibar ousa dizer que ele deve ter existido sempre. Jamais como "o discurso da moralidade universal nem o discurso da ética do debate, nem o discurso do conhecimento científico nem o discurso dos direitos do homem; nem é o discurso da tolerância, do cosmopolitismo ou da planetaridade, embora tenha certos objetivos práticos em comum com todos eles" (2018, p.82). Não se trata de um princípio regulador das diferenças, um horizonte para o qual a convergência das pluralidades resultará numa unidade sintética. Também, o fato de se tratar de mediador não alinhado a qualquer orientação doutrinária da verdade não significa que seja contra religioso. A sua areligiosidade, como diz Balibar, a sua dimensão de negação, não pode ser identificada "com ateísmo, agnosticismo ou ceticismo" (2018, p.82). O elemento balizador de um processo ultrapassa o ateísmo porque comporta as religiões sem deuses, ultrapassa o ceticismo porque envolve relações e interconexões religiosas e não se alinha ao agnosticismo porque não se apresenta como uma proposição, ou visão de mundo, entre outras. Poderíamos chamar esse mediador de secularismo se “o uso deste termo estiver acompanhado de uma crítica às instituições e às concepções reinantes de secularização - fortemente determinadas, cultural e politicamente, pelo patrimônio teológico e eclesiástico" (2018, p.82).

Como se trata de um mediador que não se identifica com qualquer das religiões em competição poderíamos aproximá-lo de um ceticismo defensor da suspensão de juízo. Balibar afirma que seria um ceticismo de "segunda potência". No entanto, diferentemente do Estado moderno herético, esse mediador só produz efeitos se ressoar entre religiões distintas e visões de mundo não religiosas sem que se imponha sobre todas elas tal como o fazem as instituições e suas regulações. Por isso mesmo, ele estaria distante do ceticismo uma vez que não se ausenta do processo das trocas simbólicas, hibridizações, filiações, distanciamentos e rupturas entre as religiões no processo de mútua tradução pública. Uma vez que atua para encetar um processo de experimentação do pluralismo a sua função é denunciar os limites e as inconsistências éticas nos discursos e doutrinas religiosos, a impossibilidade de que uma religião ambicione prescrever normas, formular juízos e classificações comparativas sobre as demais.

Esse limite a-tópico não se consuma em uma instituição, mas ele articula relações entre instituições, se consideramos as religiões como tais. E como um articulador, esse mediador tem que “despojá-los [os edifícios doutrinários] de sua singularidade e minar sua certeza de que eles detêm o monopólio da verdade e da justiça, sem, contudo, frustrar sua busca pela verdade e pela justiça ('salvação') em seus próprios caminhos” (2018, p.82). Balibar reconhece seu caráter herético uma 
vez que a sua orientação prática não responde a uma linha de comando, mas torna possível a aproximação entre linhagens concorrentes da verdade religiosa. Aqui se trataria, então, de uma compreensão fraca de heresia, mais como um não alinhamento, jamais uma confrontação. Ele evoca Espinosa para afirmar que talvez coubesse chamar esse mediador de "sabedoria (manifestamente inspirado por uma tradição grega e latina de 'sabedoria mundana' ou 'profane wisdom', 'Weltweisheit')" (2018, p.82).

Como se manifestaria tal mediador? Onde o encontraríamos? Trata-se de pensá-lo como um discurso público que age no político, não com a intenção de orientar e governar. Mas no sentido de apontar as intenções de sobreposição e exclusão religiosas; ressaltar as diferenças e peculiaridades religiosas sem ferir qualquer delas com comparações extrínsecas aos seus credos e à suas verdades específicas. Assim, ele não seria um discurso normativo, menos ainda um imperativo. Mas, como um promotor da secularização, ele se encontrou e se encontra ainda "nos antípodas das instituições estatais cuja tarefa é regular o comportamento de maneira juridicamente aplicável, ao mesmo tempo em que confere uma evidência inquestionável à distinção entre público e privado (que, na ordem do discurso, é muitas vezes redobrada pela que existe entre o expresso e o reprimido)" (2018, p.83) . Veja-se que o mediador não é a própria instância reguladora, ele não constitui o parâmetro da legalidade. Com um mediador ele terá de se localizar entre as instituições e seus sistemas reguladores. Seria esse mediador muito mais um discurso performativo, enunciação e agência seriam nele indiscerníveis. Como estamos no campo das proposições e de concertação de problemas destaca Balibar: "é bem possível que este mediador de saída não seja mais do que uma ficção filosófica. Cabe a todos nós dotar-nos de sua existência - ou inventá-lo" (2018, p.83).

\section{CONSIDERAÇÕES FINAIS: PLURALISMO HERÉTICO EM FACE DOS OPERADORES DA EXCLUSÃO}

A proposição de uma concepção herética da secularização ou de um mediador herético -em sentido fraco, digamos assim- do pluralismo coloca o pensamento de Balibar em posição muito distinta de um certo pensamento defensor da secularização e da laicidade. Ele não se alinha de modo algum aos defensores do modelo das religiões públicas. Ouisaríamos dizer que as religiões públicas se enquadrariam mais como inovações do normativismo ético e moral, ou do construtivismo social e político, ou até dos universalismos assimilacionistas do que de um sentido radical e inclusivo da laicidade e da secularização. E afirma:

De minha parte, postulo que a capacidade de enfrentar estes conflitos e de participar neles de forma civilizada com vistas a mudar o mundo não dependerá do estabelecimento de uma nova religião, mesmo que não devamos excluir 
componentes religiosos da idéia de planetaridade, especialmente em vista das dimensões apocalípticas do risco ecológico e dos medos que ele gera (2018, p.77).

Não obstante a posição de Balibar esteja distante da de Habermas, uma vez que este apenas começou a pôr em questão o suposto universalismo cosmopolita, não se pode dizer que haja uma ruptura entre eles. Habermas também defende a tradução das posições religiosas na esfera pública como um recurso para que elas se defrontem com os princípios do iluminismo. Balibar pensa que é necessário ir além. E fornece a linhagem crítica em que se apoia sua posição: "Como foi demonstrado, no entanto, por uma grande vertente do pensamento filosófico contemporâneo, de Walter Benjamin a Jacques Derrida, o intraduzível não é apenas uma barreira neste caso, um limite externo à possibilidade do encontro; é, sim, o problema que deve ser enfrentado em comum" (2018, p.80). O intraduzível e as intenções de não traduzibilidade das religiões são limites a ser transpostos sob pena de que a alteridade seja relegada ao indigno lugar do estrangeiro, como o faziam os gregos da antiguidade clássica. Mas, como dar lugar ao diferente sem evocar essa personagem ícone da irrelevância filosófica e política, sem direito de cidadania, desde Platão?

Recuperando a advertência de Mbembe em sua crítica do pensamento colonial vale ressaltar que "a identidade se origina na multiplicidade e na dispersão". Isto é, "o retorno a si só é possível no intermediário, no interstício entre a marca e a distinção, a coconstituição" (2019, p.85). Pensando em termos de um mundo das multiplicidades religiosas, ou nos termos da secularização e do pluralismo, a experiência do interstício, da experiência do intermediário da descoberta de que a integridade de cada religião faz divisa, está entre outras religiões.

Butler critica as posições que enquadram os discursos religiosos como opositores de uma linguagem pública. Esta encarnaria a figura do universal neutro e isento; aqueles o discurso localizado, restritivo, particular. Cabe perguntar: seria possível promover a democracia sem a intenção de se anular as particularidades alheias ao que as posições universalistas supostamente isentas e não assimiladoras entendem como o fundamento do comum? Afirma Butler:

O princípio é o de que a religião é uma forma de particularismo, tribalismo ou comunitarismo que deve se 'traduzir' numa linguagem comum ou racional para garantir um lugar legítimo e restrito na vida pública. Os termos do debate com frequência presumem que existe uma linguagem pública comum ou uma forma secular de razão que não são em si religiosas, mas que podem e devem servir como mediadoras das reivindicações religiosas. Fora isso, a religião ameaça se tornar a base do discurso público, da participação política e o terreno que legitima o próprio Estado (2017, p.22-3).

A laicidade como um regime de regras do Estado, uma referência para o enquadramento jurídico-político do ordenamento geral em uma sociedade, tem que ultrapassar esse limite de linguagem, que é reflexo ou consuma limites institucionais e políticos. Interessante observar, com Balibar, como e por que devemos repensar os modelos de multiculturalismo. Evitar a proposição de novos universalismos certamente poria ênfase no quão imprescindíveis são os tribunais da razão 
arbitrando os povos segundo índices articiciais marcadores do processo civilizatório, assim como as religiões segundo seu maior ou menor alinhamento a certos veios da tradição.

A laicidade herética pode se apresentar como um mediador que se abre para a construção dessa linguagem pública inclusiva. Certamente não será por esse movimento que se revolverá a opacidade das instituições políticas. Mas, talvez uma linguagem que mobilize uma laicidade herética exponha os lugares onde residem os interesses e as intenções de revitalização do estrangeiro como inimigo: esse personagem que evoca ódio, temores e está nas raízes mais fundas das políticas que operam sofisticados e bem justificados sistemas de exclusão.

\footnotetext{
$1 \mathrm{O}$ trabalho é resultado de investigação desenvolvida no âmbito do Projeto de Pesquisa financiado pelo CNPq, número: 428541/2016-0, instituição a qual também agradeço pelo financiamento.

${ }^{2}$ Habermas expõe com precisão os motivos de seu descontentamento em relação às poições assumidas por governos europeus em face do drama da imigração. A seu ver, não apenas a Carta Europeia dos Direitos Fundamentais está confrontada pelos fattos, como as posições da Europa desmentem as intenções humanistas universais, os tais princípios iluministas, que supostamente a teriam inspirado. Ele afirma "Não vejo nenhuma alternativa ao corpo de princípios do Estado social democraticamente constituído. Mas hoje as nossas instituições democráticas se tornam cada vez mais uma simples fachada para adaptar o Estado nacional aos imperativos do mercado mundial. Em uma sociedade mundial sempre fragmentada politicamente, mas altamente integrada economicamente, não dispomos de organizações que possam compensar essa lacuna e, portanto, combinar a capacidade de ação democrática e de controle democrático. Faltam hoje as premissas mínimas para a formação de regimes políticos mais amplos e mais bem-dispostos a cooperar, os quais seriam capazes de domar os mercados financeiros não regulados em escala mundial, a fim de reduzir as flagrantes desigualdades sociais que existem dentro das sociedades nacionais, mas, acima de tudo, entre os Estados e os continentes" (2019).

${ }^{3}$ Completa Balibar: "A pacificação dos conflitos religiosos, ou, melhor ainda, sua conversão ou sublimação em ideais capazes de relativizar as afiliações comunitárias, não pode funcionar no modo de multiculturalismo porque tal pacificação não se baseia apenas em processos de mudança, transição e tradução, por mais exigentes que sejam, mas tem a ver também com o que Weber chama de "a guerra dos deuses", ou seja, a incompatibilidade dos axiomas e as escolhas éticas que tais afiliações forçam os indivíduos a fazer quando a questão é a insuportável indeterminação das próprias diferenças antropológicas (2018, p.79).
}

\section{REFERÊNCIAS}

BALIBAR, E. Secularism and cosmopolitanism: critical hypotheses on religion and politics. New York : Columbia University Press, 2018.

BENHABIB, S. Another Cosmopolitanism [with commmentaries by Jeremy Waldron, Bonnie Honig and Will Kymlicka]. Oxford: Oxford University Press, 2006.

BERLIN, I. “TWO CONCEPTS OF LIBERTY,” In.: Four Essays On Liberty. Oxford: Oxford University Press, 1969. pp. 118-172.

BUTLER, J. Caminhos divergentes: judaicidade e crítica do sionismo. São Paulo: Boitempo, 2017.

HABERMAS, J.; RATZINGER, J. Dialética da secularização: sobre razão e religião. Aparecida: Ideias e Letras, 2007. 
. "Minha Cara Europa retoma a tua alma ou morrerás populista: entrevista com Jürgen Habermas". In.: Revista IHU-Online, São Leopoldo: IHU, 24/01/2019. Disponível em: http://www.ihu.unisinos.br/78-noticias/586274-minha-cara-europa-retoma-a-tua-alma-oumorreras-populista-entrevista-com-juergen-habermas Acesso em: 07/10/2020.

KOSELLECK, H. Futuro Passado - Contribuição à semântica dos tempos históricos. Rio de Janeiro: Contraponto, 2006.

MBEMBE, A. Sair da grande noite - ensaio sobre a África descolonizada. Petrópolis: Vozes, 2019.

SPIVAK, Gayatri Chakravorty. Death of a Discipline. New York: Columbia University Press, 2003.

Trabalho recebido em 24 de novembro de 2021

Aceito em 01 de novembro de 2021 